\title{
面源プルームモデルを用いた大気中の農薬濃度の予測
}

\author{
渡 辺 高 志* \\ 独立行政法人農薬検査所 \\ 干187-0011 東京都小平市鈴木町 2-772
}

(平成 14 年 4 月 8 日受付, 平成 14 年 7 月 31 日受理)

\section{Prediction of Pesticide Concentrations in the Atmosphere Using an Area Source Plume Model}

\author{
Takashi WATANABE* \\ Agricultural Chemicals Inspection Station, 2-772, Suzuki, Kodaira, Tokyo 187-0011, Japan
}

\begin{abstract}
The model to predict concentration of pesticides in the atmosphere after application on the paddy field was investigated using the Gaussian plume equation as an atmospheric diffusion model. The model was on the assumption that the pesticide was constantly discharged from the emission source, the sprayed area was topographically flat, the wind direction and the wind speed were constant. The area source was combined by $50 \mathrm{~m}$ square of mesh, and a point source was located in the center of the mesh. The emission rate was derived from the observed concentration inside the sprayed area, and it was observed that the emission rate decreased with elapsed time and the emission rate had a positive correlation with vapor pressure. The emission rate was estimated by vapor pressure, a temperature and elapsed time after application, then an emission rate, a plume height and a meteorological and geographical conditions were input into the area source plume equation, a predicted concentration was calculated. As a result, the predicted concentration showed significant correlation with the observed concentration $(p<0.01)$. The predicted concentrations generally ranged from $1 / 10$ to 10 times the observed concentrations. Therefore, this model is useful for predicting pesticide concentrations.
\end{abstract}

Key words: prediction of atmospheric concentration, area source plume model (ASPLM), pesticides, volatilization rate from paddy field.

\section{緒}

\section{言}

農薬は, 農作物を病害虫から保護するために使用され, 農作物の安定生産に資する資材の 1 つである. しかし, そ の使用に伴い, 散布中のドリフト, 散布後の農作物や土壌 の表面からの揮発により，大気環境中に残留することが知 られている.

大気中に存在する農薬による環境影響を事前に推定でき れば, 農薬の開発に当たって有益な情報が得られるので, 大気污染の予測手法として一般的な「大気拡散モデル」を 用いて，農薬を農地に散布した後の大気中濃度を予測する

\footnotetext{
* To whom correspondence should be addressed.
} E-mail: watanabe@acis.go.jp
モデルの開発を行った，大気拡散モデルは，拡散方程式に 基づくモデルと実験に基づくモデルに大別され，このうち の拡散方程式に基づくモデルには，「プルーム式 $\rfloor^{1,2)}$,「パ フ式 $\rfloor^{1,2)}$,「ボックスモデル」1) 等がある。また，発生源は, その形状により，煙突のような「点源」，道路のような 「線源」, 点源や線源が複数集合した「面源」に分けられる.

農薬散布後の大気中濃度を予測するため, 前報引ににおい て, 散布区域を 1 つの線源と仮定し, 最も簡単な予測式の 1 つである「線源プルーム式」を用いた散布区域外の濃度 を予測するモデルを開発したが， \pm 1.5 オーダー程度の予 測誤差がみられ，散布区域内の濃度を予測することはでき ないので, 散布区域をメッシュ化し，各メッシュの中心に 点源を执いた面源をつくり, 面源からの拡散を「面源プルー 
ム式」を用いて検討し, さらに，農地からの農薬の発生量 （揮発速度）を推定する方法についても検討した。

\section{方法}

\section{1. プルーム式の選定}

連続放出の発生源があり, 地形が平坦, 風向風速が一定 のとき（すなわち, 定常状態), 発生源から放出された煙 の拡散は「ガウス型プルーム式」を用いて計算できる ${ }^{1,2,4)}$. 発生源が点源の場合は, 風向軸を $\mathrm{x}$ 軸（風下側を正とす る)，これと水平面で直交する軸を $\mathrm{y}$ 軸，垂直軸を $\mathrm{z}$ 軸と すると，「点源プルーム式」は（1）式で示される。ただし， （1）式は拡散中の農薬の分解および地表沈着に伴う減量を 考慮していない.

$$
\begin{aligned}
\mathrm{C}_{\mathrm{i}}(\mathrm{x}, \mathrm{y}, \mathrm{z})= & \mathrm{Q}_{\mathrm{i}}\left(2 \pi \mathrm{U} \sigma_{\mathrm{y}} \sigma_{\mathrm{z}}\right)^{-1} \exp \left(-\mathrm{y}_{\mathrm{i}}^{2} / 2 \sigma_{\mathrm{y}}^{2}\right) \\
& \times\left[\exp \left(-\left(\mathrm{HP}+\mathrm{z}_{\mathrm{i}}\right)^{2} / 2 \sigma_{\mathrm{z}}^{2}\right)\right. \\
& \left.+\exp \left(-\left(\mathrm{HP}-\mathrm{z}_{\mathrm{i}}\right)^{2} / 2 \sigma_{\mathrm{z}}^{2}\right)\right]
\end{aligned}
$$

ここで, $\mathrm{C}_{\mathrm{i}}(\mathrm{x}, \mathrm{y}, \mathrm{z})$ は地点（x,y, $\mathrm{z}$ ) における点源から の拡散濃度 $\left(\mathrm{mg} / \mathrm{m}^{3}\right), \mathrm{Q}_{\mathrm{i}}$ は点源の発生量 $(\mathrm{mg} / \mathrm{sec}), \mathrm{U}$ は 風速 $(\mathrm{m} / \mathrm{sec}) ， \sigma_{\mathrm{y}}$ と $\sigma_{\mathrm{z}}$ はそれぞれ水平拡散幅 $(\mathrm{m})$ と垂直 拡散幅 $(\mathrm{m}), \mathrm{HP}$ はプルーム高 $(\mathrm{m}), \mathrm{y}_{\mathrm{i}}$ と $\mathrm{z}_{\mathrm{i}}$ はそれぞれ 地点（x，y，z）の $\mathrm{y}$ 軸距離（m) と地上高（m) である. HP は, 発生源が煙突の場合の「有効煙突高」と称される が，農地からのプルームの拡散計算にあたり，本論文中で は「プルーム高」と称する， $\sigma_{\mathrm{y}}$ と $\sigma_{\mathrm{z}}$ は，パスキルによる 大気安定度 ${ }^{4)}$ ごとの分類による風下距離 $\left(\mathrm{x}_{\mathrm{i}}\right)$ からの経験 式 ${ }^{5)}$ から計算し（Table 1)，この式は日本における大気中 の窒素酸化物の規制に用いられている5).なお，この大気 安定度は風速と日射量（夜間は雲量）を基に強不安定（A） から並安定（F）まで 6段階に分類されている.

次に, 発生源が面源の場合, 面源を幾つかのメッシュで 区切り，1つのメッシュの中心に点源をおく１つのメッ シュにおける発生量を 1 つの点源に集約して $\mathrm{Q}_{\mathrm{i}}(\mathrm{mg} / \mathrm{mesh} /$

\begin{tabular}{|c|c|c|c|c|c|c|}
\hline \multirow{2}{*}{$\begin{array}{l}\text { Atmospheric } \\
\text { Stability }^{b} \text { ) }\end{array}$} & \multicolumn{3}{|c|}{$\left.\sigma_{y}{ }^{a}\right)=\gamma_{y} \cdot x_{i}{ }^{\alpha y}$} & \multicolumn{3}{|c|}{$\sigma_{z}{ }^{0)}=\gamma_{z} \cdot x_{i}{ }^{\alpha}$} \\
\hline & $\gamma_{\mathrm{y}}$ & $\alpha_{y}$ & $x_{i}{ }^{c)}$ & $\gamma_{z}$ & $\alpha_{\mathrm{z}}$ & $x_{i}{ }^{c)}$ \\
\hline \multirow[t]{3}{*}{ A } & 0.426 & 0.901 & $0-1000$ & 0.0800 & 1.122 & $0-300$ \\
\hline & 0.602 & 0.851 & $1000-$ & 0.00855 & 1.514 & $300-500$ \\
\hline & 0.000212 & 2.109 & $500-$ & & & \\
\hline \multirow[t]{2}{*}{ B } & 0.282 & 0.914 & $0-1000$ & 0.1272 & 0.964 & $0-500$ \\
\hline & 0.396 & 0.865 & $1000-$ & 0.0570 & 1.094 & $500-$ \\
\hline \multirow[t]{2}{*}{$\mathrm{C}$} & 0.1772 & 0.924 & $0-1000$ & 0.1068 & 0.918 & 0 \\
\hline & 0.232 & 0.885 & $1000-$ & & & \\
\hline \multirow[t]{2}{*}{$\mathrm{D}$} & 0.1107 & 0.929 & $0-1000$ & 0.1046 & 0.826 & $0-1000$ \\
\hline & 0.1467 & 0.889 & $1000-$ & 0.400 & 0.632 & $1000-$ \\
\hline \multirow[t]{2}{*}{$\mathrm{E}$} & 0.0554 & 0.929 & $0-1000$ & 0.0928 & 0.788 & $0-1000$ \\
\hline & 0.0733 & 0.889 & $1000-$ & 0.433 & 0.565 & $1000-$ \\
\hline \multirow[t]{2}{*}{$\mathrm{F}$} & 0.0380 & 0.921 & $0-1000$ & 0.0621 & 0.784 & $0-1000$ \\
\hline & 0.0452 & 0.896 & $1000-$ & 0.370 & 0.526 & $1000-$ \\
\hline
\end{tabular}
sec）とする.「面源プルーム式」は，全てのメッシュから

Table 1. Atmospheric diffusion width ${ }^{5)}$

a) $\sigma_{\mathrm{y}}$ is horizontal diffusion width $(\mathrm{m})$ and $\sigma_{\mathrm{z}}$ is vertical diffusion width (m).

b) Atmospheric stability by Pasquill, ${ }^{4}$ A: strongly unstable, B: middle unstable, C: weakly unstable, D: neutral, E: weakly stable, F: middle stable.

${ }^{c)} \mathrm{X}_{\mathrm{i}}$ is downwind distance $(\mathrm{m})$. 
の拡散を積分した次式で示される.

$$
\mathrm{C}(\mathrm{x}, \mathrm{y}, \mathrm{z})=\Sigma \mathrm{C}_{\mathrm{i}}(\mathrm{x}, \mathrm{y}, \mathrm{z})
$$

ここで, $\mathrm{C}(\mathrm{x}, \mathrm{y}, \mathrm{z})$ は地点（x, y, z) における面源から の拡散濃度 $\left(\mathrm{mg} / \mathrm{m}^{3}\right)$.

\section{2. 大気中濃度の測定データ}

予測モデルの開発に当たって使用したデータ ${ }^{6-15)}$ は, 農 薬散布後に大気中濃度を測定し, 同時に気象条件が調査さ れ, 濃度測定地点之散布区域との地理的関係が明らかとなっ ている調查報告から引用した（Table 2)。調查対象農薬は 13 種, 調查地域は延べ 42 力所である. 対象地域は全て水 田，作物は水稲であり，農薬散布時の生育ステージは，概 社減数分裂期から出穂期, 散布時の作物の高さは約 $1 \mathrm{~m}$ であった，大気中濃度の測定高は，ほとんどの場合，地上 $1.5 \mathrm{~m}$ であった. 大気中濃度の測定地点は, 圃場内の地点 と散布境界から $2 \mathrm{~km}$ 以内の地点であり, 風下側の地点の データのみ利用した。 大気中濃度は, 散布直後から最長 5 日後まで経時的に測定された。

\section{3. パラメーターの検討}

農薬を散布した農地全体を発生源（面源）とし， $50 \mathrm{~m}$ 四方にメッシュ化する．各メッシュの中心に点源をおく．

(1) 式中のパラメーターのうち，U, $\sigma_{y}, \sigma_{z}, y_{i}$ 及び $z_{i}$ は気象条件之地理条件から決定される。 HP は, 発生源の 地上高とプルームの上昇分の合計で定義されるあのであり, 作物から揮発したプルームは熱量をむたないため上昇しな いと考えられるので, 作物の高さ（1 m) を定数值として 使用した。 $\mathrm{z}_{\mathrm{i}}$ は, 大気中濃度の実測高の $1.5 \mathrm{~m}$ を使用した。 従って, 発生量 $\mathrm{Q}$ のみが未知の变数である.

\section{1. 発生量の計算}

実際の圃場において, 発生量の実測值を得ることは難し く，今回利用したデー夕では測定されていなかったため発 生量を推定した。

$50 \mathrm{~m}$ 四方のメッシュの中心を原点とし, 点源をおいた. 次に, 当該メッシュ内の点源からの拡散によるメッシュ中 心での濃度は $\mathrm{x}_{\mathrm{i}}=0 \mathrm{~m}$ となるため求められないので, 当該 メッシュと風下側で隣接するメッシュとの $\mathrm{x}$ 軸上の中間地 点（ $\mathrm{x}, \mathrm{y}, \mathrm{z}=25 \mathrm{~m}, 0 \mathrm{~m}, 1.5 \mathrm{~m}$ ) を散布区域内での測定地 点と仮定し, 区域内での測定濃度, 測定時のパラメーター （風速等）及び中間地点の座標を（1）式に入力し, 散布区 域内での測定データ全てについて，50 mメッシュからの 発生量 $\mathrm{Q}_{\mathrm{i}}(\mathrm{mg} / \mathrm{mesh} / \mathrm{sec})$ を逆算した。

次に, 農薬散布条件は Table 2 に示したとおり, 農薬ご とで異なっていたので， $\mathrm{Q}_{\mathrm{i}}$ を単位面積当たりの有効成分 投下量 (AR: $\left.\mathrm{g} / \mathrm{m}^{2}\right)$ で除して $\mathrm{Q}_{i}{ }^{\prime}\left[\left(\mu \mathrm{g} / \mathrm{m}^{2} / \mathrm{sec}\right) /\left(\mathrm{g} / \mathrm{m}^{2}\right)\right]$ を求 めた。 $\mu \mathrm{g} / \mathrm{m}^{2} / \mathrm{sec}$ を $\mathrm{g} / \mathrm{m}^{2}$ で割ることにより単位の変換が図
(1) fenitrothion

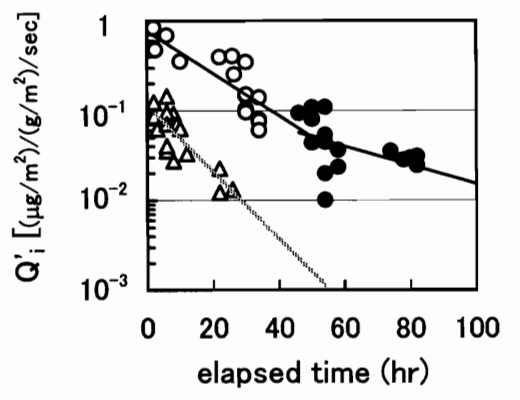

$O: A-C(<40 h r), O: A-C(>40 h r), \Delta: D$

\section{(2) fenobucarb}

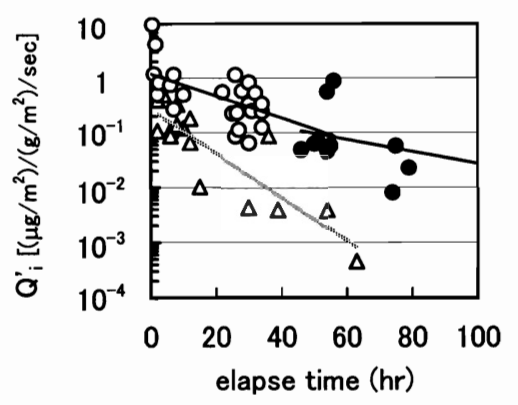

$\mathrm{O}: \mathrm{A}-\mathrm{C}(\langle 40 \mathrm{hr}), \mathrm{O}: \mathrm{A}-\mathrm{C}(>40 \mathrm{hr}), \Delta: \mathrm{D}$

Fig. 1. Relationship between emission rates $\left(Q_{i}{ }^{\prime}\right)$ and elapsed time (t).

(1) fenitrothion

$\mathrm{Q}_{i}{ }^{\prime}=0.773 \exp (-0.0543 \mathrm{t}) ; 0-40 \mathrm{hr}, \mathrm{A}^{-} \mathrm{C}, \mathrm{r}^{2}=0.77$

$\mathrm{Q}^{\prime}{ }^{\prime}=0.175 \exp (-0.0244 \mathrm{t}) ;>40 \mathrm{hr}, \mathrm{A}^{-} \mathrm{C}, \mathrm{r}^{2}=0.31$

$\mathrm{Q}^{\prime}=0.115 \exp (-0.0856 \mathrm{t}) ; \mathrm{D}, \mathrm{r}^{2}=0.67$

(2) fenobucarb

$\mathrm{Q}_{\mathrm{i}}{ }^{\prime}=1.192 \exp (-0.0467 \mathrm{t}) ; 0-40 \mathrm{hr}, \mathrm{A}^{-} \mathrm{C}, \mathrm{r}^{2}=0.42$

$\mathrm{Q}^{\prime}{ }^{\prime}=0.343 \exp (-0.0254 \mathrm{t}) ;>40 \mathrm{hr}, \mathrm{A}^{-} \mathrm{C}, \mathrm{r}^{2}=0.11$

$\mathrm{Q}^{\prime}=0.263 \exp (-0.0914 \mathrm{t}) ; \mathrm{D}, \mathrm{r}^{2}=0.75$

*: An emission rate from 1 mesh $\left(\mu \mathrm{g} / \mathrm{m}^{2} / \mathrm{sec}\right)$ divided by an application rate of active ingredient $\left(\mathrm{g} / \mathrm{m}^{2}\right)$ is $\mathrm{Q}_{i}^{\prime}$.

られるが，わかりやすくするため単位の変換はしなかった．

$$
\mathrm{Q}_{\mathrm{i}}{ }^{\prime}=\mathrm{Q}_{\mathrm{i}} / \mathrm{AR}
$$

\section{2. 発生量の推定}

大気中濃度の対数值を散布後の経過時間に対してプロッ 卜すると負の相関が得られるので， $\mathrm{Q}^{\prime}$ 'の対数值を経過時 間に対してプロットしたところ，同様に負の相関が得られ た。この相関は，大気安定度が $\mathrm{A} \sim \mathrm{C}$ のとき（天候が晴） と大気安定度が D (天候が曇) のときの 2 つのパターンに 分かれた。 なお，大気安定度 $F, F$ に該当する測定はなかっ た。これは, 日射量が葉面温度に影響し, 発生量に違いを 生じさせたためと考えられる。大気安定度の違いにより $\mathrm{Q}^{\prime}$ が異なったので，以降は，この 2 つのパターンごとに 
Table 2. Measurement data of concentration of pesticides in the atmosphere after its application on paddy field

\begin{tabular}{|c|c|c|c|c|c|}
\hline \multirow{2}{*}{ Pesticide } & \multicolumn{2}{|c|}{ Sampling area } & \multicolumn{2}{|c|}{ Application condition } & \multirow{2}{*}{ ref. } \\
\hline & date & place & rate ${ }^{\bullet}$ & area(ha) & \\
\hline \multirow[t]{4}{*}{ buprofezin } & 89.8.19-8.21 & Saitama Pref., Misato & 0.020 & 570 & 7 \\
\hline & $91.8 .14-8.18$ & Saitama Pref., Misato & 0.020 & $-b)$ & 11 \\
\hline & 92.8.14-8.27 & Saitama Pref., Oosato & 0.020 & - & 12 \\
\hline & $93.8 .15-8.22$ & Saitama Pref., Oosato & 0.020 & 500 & 13 \\
\hline \multirow[t]{2}{*}{ diazinon } & $88.7 .30-8.1$ & Saitama Pref., Hanyuu & 0.025 & 760 & 15 \\
\hline & $88.7 .30-8.1$ & Saitama Pref., Hanyuu & 0.025 & 760 & 7 \\
\hline \multirow[t]{8}{*}{ fenitrothion } & 88.8. 3-8. 5 & Chiba Pref., Sakura & 0.045 & 375 & 8 \\
\hline & 88.8. 3-8. 8 & Chiba Pref., Sakura & 0.045 & 375 & 7 \\
\hline & 89.8. 7-8. 9 & Chiba Pref., Sakura & 0.045 & 375 & 15 \\
\hline & $89.8 .10-8.13$ & Niigata Pref., Jouetsu & 0.045 & 143 & 9 \\
\hline & $91.7 .23-8.13$ & Chiba Pref., Sakura & 0.045 & - & 11 \\
\hline & $92.7 .30-8.18$ & Chiba Pref., Sakura & 0.045 & - & 12 \\
\hline & $93.7 .27-8.18$ & Chiba Pref., Sakura & 0.045 & 270 & 13 \\
\hline & $93.6 .17-7.18$ & Niigata Pref., Maki & 0.050 & 2,014 & 13 \\
\hline \multirow[t]{9}{*}{ fenobucarb } & $87.8 .25-8.29$ & Saitama Pref., Hanyuu & 0.040 & 760 & 6 \\
\hline & 88.8. 3-8. 5 & Chiba Pref., Sakura & 0.040 & - & 8 \\
\hline & $88.7 .30-8.21$ & Saitama Pref., Hanyuu & 0.040 & - & 15 \\
\hline & 89.8. 7-8. 9 & Chiba Pref., Sakura & 0.040 & 375 & 14 \\
\hline & 88.8. 1-8. 8 & Niigata Pref., Niigata & 0.040 & 1,100 & 9 \\
\hline & 89.7.24-7.29 & Niigata Pref., Niigata & 0.040 & 1,085 & 9 \\
\hline & $91.7 .23-8.23$ & Chiba Pref., Sakura & 0.040 & - & 11 \\
\hline & $92.7 .30-8.28$ & Chiba Pref., Sakura & 0.040 & - & 12 \\
\hline & $93.7 .27-8.28$ & Chiba Pref., Sakura & 0.040 & 270 & 13 \\
\hline fenthion & $88.8 .15-8.16$ & Ibaraki Pref., Ishige & 0.050 & 621 & 7 \\
\hline \multirow[t]{3}{*}{ malathion } & $87.8 .25-8.26$ & Saitama Pref., Hanyuu & 0.030 & 760 & 6 \\
\hline & 88.8. 1-8. 5 & Niigata Pref., Niigata & 0.030 & 1,100 & 9 \\
\hline & 89.7.24-7.26 & Niigata Pref., Niigata & 0.030 & 1,085 & 9 \\
\hline pyridafenthion & $94.7 .6-7.15$ & Niigata Pref., Maki & 0.040 & 2,050 & 7 \\
\hline \multirow[t]{3}{*}{ tetrachlorvinfos } & $88.6 .26-7.21$ & Niigata Pref., Niigata & 0.038 & 1,100 & 9 \\
\hline & $89.6 .27-6.30$ & Niigata Pref., Niigata & 0.038 & 1,085 & 9 \\
\hline & 91.8. 1-8.10 & Niigata Pref., Nishikawa & 0.0375 & 670 & 11 \\
\hline trichlorfon & 88.8. 5-8.10 & Gunma Pref., Chiyoda & 0.0525 & 461 & 7 \\
\hline \multirow[t]{5}{*}{ fthalide } & $91.8 .14-8.18$ & Saitama Pref., Misato & 0.020 & - & 7 \\
\hline & $92.8 .14-8.27$ & Saitama Pref., Oosato & 0.020 & - & 12 \\
\hline & $93.8 .15-8.22$ & Saitama Pref., Oosato & 0.020 & 500 & 13 \\
\hline & $93.8 .8-8.16$ & Niigata Pref., Maki & 0.020 & 2,014 & 13 \\
\hline & $94.8 .8-8.16$ & Niigata Pref., Maki & 0.025 & 2,050 & 14 \\
\hline isoprothiolane & $90.8 .21-8.23$ & Tochigi Pref., Ashikaga and Sano & 0.040 & 308 & 10 \\
\hline mepronil & 89.7.30-8. 1 & Miyagi Pref., Sanbongi & 0.048 & 400 & 7 \\
\hline \multirow[t]{3}{*}{ tricyclazole } & 89.7.30-8. 1 & Miyagi Pref., Sanbongi & 0.013 & 400 & 7 \\
\hline & $93.7 .20-7.28$ & Niigata Pref., Maki & 0.012 & 2,014 & 13 \\
\hline & $94.7 .22-8.22$ & Niigata Pref., Maki & 0.012 & 2,050 & 14 \\
\hline
\end{tabular}

a) Application rate (AR: $\mathrm{g} / \mathrm{m}^{2}$ ) shows weight of active ingredient.

b) Unreported.

検討した。減衰定数 $\mathrm{k}\left(\mathrm{hr}^{-1}\right)$ は Fig. 1 に示したように, 大 気安定度が A から C の場合のみ散布約 40 時間後以降に, $\mathrm{Q}_{i}{ }^{\prime}$ の相関式の傾きが小さくなった，光分解の促進等によ
る発生源（圃場）内での稲体中の農薬濃度の低下のためと 考えられたので $\mathrm{k}$ を 2 つ分け, 散布直後から 40 時間後 までを $\mathrm{k}_{1}, 40$ 時間後以降を $\mathrm{k}_{2}$ とした. 


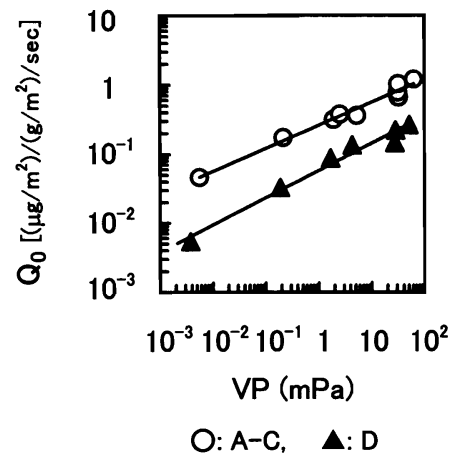

Fig. 2. Relationship between initial emission rates $\left(\mathrm{Q}_{0}\right)$ and vapor pressures (VP).

$\mathrm{Q}_{0}=0.2600 \mathrm{VP}^{\wedge} 0.3306, \mathrm{~A}^{-} \mathrm{C}, \mathrm{n}=9, \mathrm{r}^{2}=0.97$

$\mathrm{Q}_{0}=0.0578 \mathrm{VP}^{\wedge} 0.3937, \mathrm{D}, \mathrm{n}=7, \mathrm{r}^{2}=0.97$

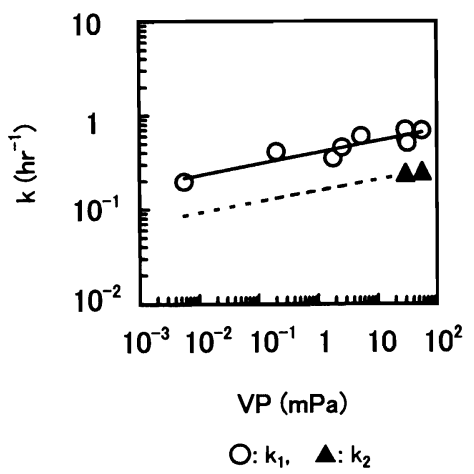

Fig. 3. Relationship between decreasing constants (k) and vapor pressures.

$$
\mathrm{k}_{1}=0.0405 \mathrm{VP}^{\wedge} 0.1215, \mathrm{n}=9, \mathrm{r}^{2}=0.84
$$

$\mathrm{k}_{2}=0.0160 \mathrm{VP}^{\wedge} 0.1215, \mathrm{n}=2$

*: It was assumed that the exponent of $k_{2}$ was equal to it of $k_{1}$.

発生量と経過時間の相関の代表例として, $\mathrm{k}_{1}$ と $\mathrm{k}_{2}$ を求 めることができた fenitrothion と fenobucarbをそれぞれ Fig. 1（1）と Fig. 1（2）に示す．この相関から， Qi'は（4） 式で示される.

$$
\mathrm{Q}_{\mathrm{i}}{ }^{\prime}=\mathrm{Q}_{0} \exp (-\mathrm{kt})
$$

ここで， $\mathrm{Q}_{0}$ は 0 時間のときの $\mathrm{Q}_{\mathrm{i}}{ }^{\prime}\left[\left(\mu \mathrm{g} / \mathrm{m}^{2} / \mathrm{sec}\right) /\left(\mathrm{g} / \mathrm{m}^{2}\right)\right], \mathrm{k}$ は減衰定数 $\left(\mathrm{hr}^{-1}\right), \mathrm{t}$ は散布後の経過時間 $(\mathrm{hr})$.

次に, 植物体の表面からの農薬の揮発速度 $\left(\mathrm{hr}^{-1}\right)$ は, 蒸気圧（VP）との間に高い相関をむつことが認められて いるので16), 農薬ごとの $\mathrm{Q}_{0}$ あるいは $\mathrm{k}$ と $\mathrm{VP}$ との相関を 調べた（Fig. 2 と Fig. 3). その際，蒸気圧は温度により変 動するため, 大気中濃度を測定したときの気温の平均値を 求め, Clapeyron-Clausius 式（5）を用いて蒸気圧デー夕を 気温で補正した。

$$
\mathrm{VP}_{\mathrm{j}}=\mathrm{VP}_{\mathrm{k}} \exp \left(-\Delta \mathrm{H} / \mathrm{R}\left(1 / \mathrm{T}_{\mathrm{j}}-1 / \mathrm{T}_{\mathrm{k}}\right)\right)
$$

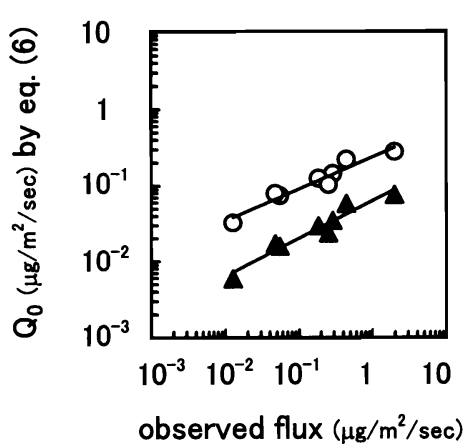

O: A-C, $\Delta: D$

Fig. 4. Correlation between observed emission rates (flux) and $\mathrm{Q}_{0}$ calculated by equation (6).

*: $\mathrm{Q}_{0}$ was calculated under the assumption that application rate (AR) was $0.035 \mathrm{~g} / \mathrm{m}^{2}$ which was the average of AR in Table 2 .

ここで, $\mathrm{VP}_{\mathrm{j}}$ と $\mathrm{VP}_{\mathrm{k}}$ は温度 $\mathrm{T}_{\mathrm{j}}$ と $\mathrm{T}_{\mathrm{k}}(\mathrm{K})$ における蒸気圧. $\mathrm{R}$ は気体定数で $8.314 \mathrm{~J} \mathrm{~K}^{-1} \mathrm{~mol}^{-1}$. $\Delta \mathrm{H}$ は相転移の潜熱で 50 $\mathrm{kJ} \mathrm{mol}^{-117)}$.

なお， $\mathrm{k}_{1}$ 值に大気安定度 $\mathrm{A} \sim \mathrm{C}$ と $\mathrm{D}$ による大きな違い はみられなかったので，両者を平均した。その結果， $\mathrm{Q}_{0}$ 及び $\mathrm{k}$ は蒸気圧之正の相関がみられたので, それぞれ，

（6）式と（7）式で示される経験式が得られた。

$$
\begin{aligned}
& \mathrm{Q}_{0}=\mathrm{AQ} \cdot \mathrm{VP}^{\mathrm{BQ}} \\
& \mathrm{k}=\mathrm{Ak} \cdot \mathrm{VP}^{\mathrm{Bk}}
\end{aligned}
$$

ここで, $\mathrm{AQ}$ と $\mathrm{BQ}$ 及び $\mathrm{Ak}$ と $\mathrm{Bk}$ は定数, $\mathrm{VP}$ は蒸気圧 $(\mathrm{mPa})$. ただし， $\mathrm{k}_{2}$ と VPの相関については, $\mathrm{k}_{2}$ のデー夕 数が fenitrothion と fenobucarb の 2 つのと少なかったた め， $\mathrm{k}_{1}$ と VP の相関と同一の傾きをあつと考え， Bkをそ のまま使用した。

\section{結果及び考察}

\section{1. 発生量の検証}

Q 0 の計算方法を検証するため, Woodrow らによる植物 やガラス等の表面からの単位面積当たりの揮発速度（flux: $\left.\mu \mathrm{g} / \mathrm{m}^{2} / \mathrm{sec}\right)^{18)}$ と比較した. Woodrow らが利用した 12 種類 の化合物のうち, 今回の供試農薬のVPの範囲である $10^{-2} \sim$ $10^{2} \mathrm{mPa}$ の 8 化合物について, 大気安定度 $\mathrm{A} \sim \mathrm{C}$ と大気安 定度 $\mathrm{D} \sim \mathrm{E}$ ごとに, Woodrow らの蒸気圧を（6）式に代入 した $\mathrm{Q}_{0}$ と揮発速度の実測值を比較した. $\mathrm{Q}_{0}$ の単位を揮発 速度の単位に統一するための AR は, Table 2 の農薬散布 条件の平均値 $0.035 \mathrm{~g} / \mathrm{m}^{2}$ を使用した. その結果, (6) 式か ら求めた $\mathrm{Q}_{0}$ と揮発速度の実測值の間に正の相関がみられ （大気安定度 $\mathrm{A} \sim \mathrm{C}, \mathrm{D}$ とも $\mathrm{r}=0.93$ ), 同一化合物の $\mathrm{Q}_{0}$ と 揮発速度を比べるとほぼ同じオーダーであった（Fig. 4).な お, 揮発速度は, 気温が $20-30^{\circ} \mathrm{C}$ で測定されたあのであり, 大気安定度は不明であった。 
(1) Distance from sprayed area

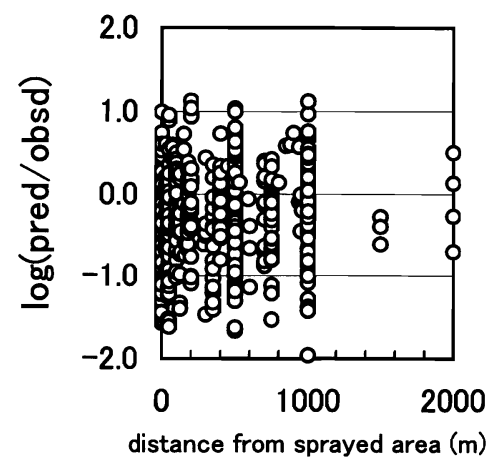

(2) Elapsed time

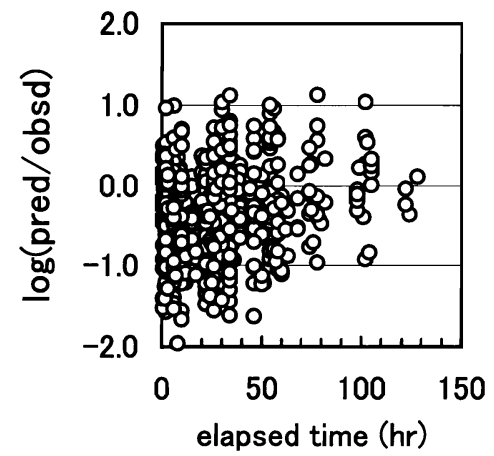

(3) Vapor pressure

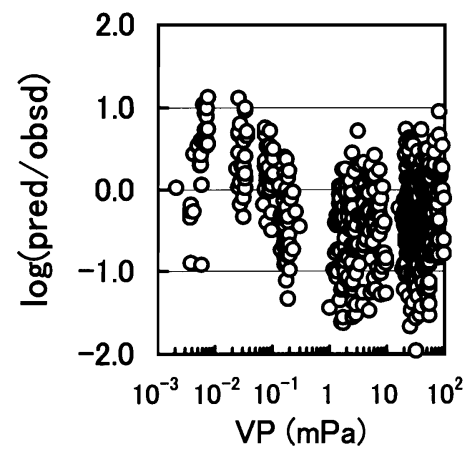

Fig. 5. Distribution of $\log ($ pred/obsd) by distance from sprayed area, elapsed time and vapor pressure of pesticides.

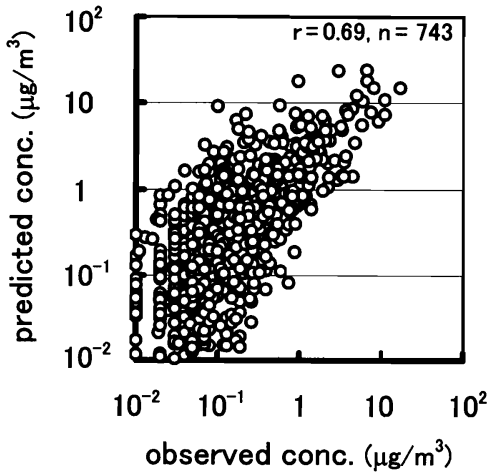

Fig. 6. Correlation between observed concentrations and predicted concentrations.

\section{2. 予測精度}

農薬の VP （6）式と（7）式に代入して， $\mathrm{Q}_{0}$ と $\mathrm{k}$ を 求めた。なお，VPは（5）式を用いて大気中濃度が測定 された時の気温で変換しておく．散布後の経過時間 $\mathrm{t}$ から, その時点での $\mathrm{Q}^{\prime}$ を（4）式により計算し，さらに（3）式 により単位面積当たりの有効成分投下量 $\mathrm{AR}$ 加ら $\mathrm{Q}_{\mathrm{i}}$ を求 めた。面源は， $50 \mathrm{~m}$ 四方のメッシュで構成し，風上側に 20 メッシュ, 左右に 20 メッシュずつを配置した。 従って, 面源の大きさは幅 $2050 \mathrm{~m}$ ，奥行 $1000 \mathrm{~m}$ である．ただし， 奥行については実際の圃場の大きさに合わせて入力した. 各メッシュの中心に上記 $\mathrm{Q}_{\mathrm{i}}$ をむつ点源を置き，個々の点 源からの拡散を計算するため，気象条件と地理的条件を （1）式に代入し，さらに，全ての点源分を（2）式により 合計して予測濃度を求めた。

（予測濃度実測濃度）の対数值（以下，「 $\log$ 值」と略す） を求め, $\log$ 值を散布区域からの距離，散布後の経過時間 あるいは蒸気圧の違いに対してプロットしたところ, 距離, 経過時間, 蒸気圧の違いによる $\log$ 值に偏りはみられず (Fig. 5)， $\log$ 值全体では 0 を中心とした分布を示し， $\log$ 值の標準偏差（SD）は 0.51 であった。中央值 $\pm 2 \times \mathrm{SD}$ で 全体の $95.5 \%$ 占めるので，この $2 \mathrm{SD}$ を予測誤差とする
と $10^{\wedge}(0.51 \times 2)=11$ となり, 予測值と実測值は約 \pm 1 オー ダーの範囲で一致することを示し，また，両者の間には危 険率 $1 \%$ で有意な相関が認められた（r=0.69, Fig. 6). Table 2 に示したデータのうち, 散布区域外で測定された あのについて, 線源プルーム式を用いて予測した濃度と実 測值を比較した場合の相関係数が $0.52, \log$ 值の SD が

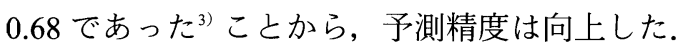

今回利用したデー夕は，大気の吸引を 20 分から 1 時間 かけて行ったもので大気中濃度は平均値となり, 風向之風 速む同一時間における平均を用いたが，風向之風速は常に 変動するものである。これらの変動をパラメーターとして モデルに組み込むこと等による改良の必要があると考えら れる。

\section{要 約}

大気污染の予測手法として一般的な「大気拡散モデル」 を用いて，農薬を農地に散布した後の大気中濃度を予測す るモデルの開発を行った。モデルでは，連続放出の発生源， 平坦な地形, 一定の風向風速を仮定し,「ガウス型プルー ム式」を用いた。ささらに，水田全体を発生源とし， $50 \mathrm{~m}$ 四方にメッシュ化し，各メッシュの中心に発生点源をおき, 面源を構成させた。散布区域内で測定された濃度加ら発生 量を逆算し, これと蒸気圧, 気温, 散布後の経過時間との 相関を調へ，発生量を推定する方法を検討した。

この推定式を用いて発生量を計算し, 気象条件之地理的 条件等のパラメーターを面源プルーム式に代入して予測濃 度を求めた。予測濃度と実測濃度を比較してモデルの適合 性を調べたところ, 散布区域からの距離, 散布後の経過時 間，蒸気圧の違いに影響されず，危険率 $1 \%$ で有意な相関 が認められ，約士1オーダーの範囲でほぼ一致した。

農薬を散布した後の農地からの発生量（揮発速度）は, 蒸気圧（今回のシミュレーションに利用した農薬の範囲は $10^{-3} \sim 10^{2} \mathrm{mPa}$ ） と気温・経過時間（散布 5 日後まで）で 計算でき，発生源から揮発した農薬の拡散についても，散 
布区域から風下 $1 \sim 2 \mathrm{~km}$ まではプルーム式で計算できる ことを確認した。

\section{引用 文 献}

1) 横山長之 : 大気污染の機構之解析一環境科学特論, 鈴木武 夫編, 産業図書, pp. 37-66, 1980.

2) 横山長之：大気環境シミュレーション一大気の流れと拡散一, 横山長之編, 白覀書房, pp. 1-67, 1992.

3) T. Watanabe: Chemosphere 40, 79-90 (2000).

4) F. Pasquill and F. B. Smith: "Atmospheric Diffusion (Third Edition)," Ellis Horwood Publisher, 1983.

5) 環境庁大気保全局大気規制課：窒素酸化物総量規制マニュ アル，公害研究対策センター, pp. 130-179, 1982.

6) 農林水産航空協会：昭和 62 年度農林水産航空技術合理化 試験成績書, 1988 .

7) 農林水産航空協会 : 平成元年度農林水産航空技術合理化試 験成績書, 1990.

8) 渡辺高志：農薬検査所報告 30，19-28（1990）。

9) 新潟県衛生公害研究所: 平成 63 年度, 平成元年度特定研
究報告書「薬剤の空中散布による環境中の分布等に関する 調査研究」, 1990.

10) 農林水産航空協会 : 平成 2 年度農林水産航空技術合理化試 験成績書, 1991.

11）農林水産航空協会 : 平成 3 年度農林水産航空技術合理化試 験成績書, 1992.

12) 農林水産航空協会 : 平成 4 年度農林水産航空技術合理化試 験成績書, 1993.

13）農林水産航空協会：平成 5 年度農林水産航空技術合理化試 験成績書, 1994.

14）農林水産航空協会 : 平成 6 年度農林水産航空技術合理化試 験成績書, 1995.

15) 渡辺高志：未発表.

16) T. Watanabe: J. Pesticide Sci. 18, 201-209 (1993).

17) National Institute of Public Health and the Environment (RIVM), the Netherlands: Simple Box 2.0, a nested multimedia fate model for evaluating the environmental fate of chemicals, 1996.

18) J. E. Woodrow, J. N. Seiber and L. W. Baker: Environ. Sci. Technol. 31, 523-529 (1997). 